\section{Identity-related attitude in the child development centres for protecting educational asylum of early childhoods: From rural communities to schooling cities}

\author{
Jirawon Tanwattanakul ${ }^{1 *}$, Nilawan Chantapreeda ${ }^{1}$ and \\ Toansakul Tony Santiboon ${ }^{2}$
}

${ }^{1}$ Department of the Child Health Nursing, Faculty Nursing, Khon Kaen University, Khon Kaen, Thailand ${ }^{2}$ Department of SMEC, Curtin University of Technology, Perth, WA, Australia

\section{Abstract}

The global identities of parents' popularity in rural communities to make-decision effects of their attitudes to transfer their Early Childhood from Child Development Centres and Local Primary School for moving study into the schooling cities that looks like children' asylum of their educational conditions, problems, administration' school directors, teachers, and schools' environments to protect that described. The involving CDCs' perceptions got using the 25-item My CDC Identity Inventory (MCDCII) in five scales, three options. Teacher and Caregiver-Early Childhood interactions have assessed with the 30-item Questionnaires on Teacher Identity Interaction (QTII) in five scales on five options. The 10-item Local Identity-Related Attitude (LIRA) has been associated with a sample of 300 children's parents, teachers, and caregivers. The determination of efficient predictive value $\left(R^{2}\right)$ shows that $30 \%$ of accepted the identities on cohesiveness, competitiveness, physical indoor and outdoor environmental development, satisfaction, and strong-sense identity. $74 \%$ of their CDCs can protect the educational asylum of early childhoods from rural communities. The $\mathrm{R}^{2}$ value shows $49 \%$ of the variance in children's parents' perceptions was because of the MCDCII have associated. Despite Thailand's success in expanding educational access, new empirical evidence suggests that much more needs to be done to maximize the potential of its students. The performance gaps among schools have disadvantaged and poorer-performing students have concentrated in small rural village schools. The Thai pre-primary school system is dramatically lacking in qualified the CDCs' learning environments and achievements, and teachers. It allocated small rural schools teachers with lower qualifications and teaching experience.

\section{More Information}

*Address for Correspondence: Dr. Jirawon Tanwatthanakul, Associate Professor, Department of the Child Health Nursing, Faculty Nursing, Khon Kaen University, 123 Mittrapab Highway, Muang District, Khon Kaen, Thailand 40002, Email: jirtan@kku.ac.th; toansakul35@yahoo.com.au

Submitted: August 16, 2021

Approved: September 09, 2021

Published: September 13, 2021

How to cite this article: Tanwattanakul J, Chantapreeda N, Santiboon TT. Identity-related attitude in the child development centres for protecting educational asylum of early childhoods: From rural communities to schooling cities. J Adv Pediatr Child Health. 2021; 4: 084-092.

DOI: 10.29328/journal.japch.1001039 ORCiD: orcid.org/0000-0001-7344-206X

Copyright: @ 2021 Tanwattanakul J, et al. This is an open access article distributed under the Creative Commons Attribution License, which permits unrestricted use, distribution, and reproduction in any medium, provided the original work is properly cited.

Keywords: Local identity-related attitude; The Child Development Centres; Protecting educational asylum; Early childhoods in rural communities; Schooling cities; Teachers and care givers

Check for updates

OPEN ACCESS

\section{Introduction}

Education in Thailand is provided mainly by the Thai government through the Ministry of Education from preschool to upper secondary educational school that mandates nine years of "basic education." Free basic education of fifteen years is guaranteed by the constitution [1]. Children are enrolled in primary school from the age of six and attend for six years; Grade 1 to Grade 6 . Secondary education starts at age 13 [2]. It consists of three years of lower secondary education, Grade 7 to Grade 9 (age 13-15), and three years of upper secondary education, Grade 10 to Grade 12 (age 16-18) [3]. Pre-primary education was introduced in 2004 and made free in 2009. State schools offer two years of early childhood (age 3-4-year-olds) and one year of pre-school studies (age 5-yearolds). At the age of six, education begins. The village and subdistrict schools usually provide pre-school early childhood and primary classes, while in the district towns; schools will serve their areas with comprehensive schools with all the classes from early childhood [4]. Rural schools are generally less well equipped than the schools in the cities; students will commute 60-80 kilometers to schools in the nearest city. The school year is divided into two semesters [5].

Thailand has a particular interpretation of education for sustainable development (ESD), including the National 
Economic and Social Development Plan and the National Education Act [6]. The eight learning standards defined in a scaffold manner for each subject area by eight characteristics including active learning, sufficiency lifestyle, and public mindedness with learning modules are developed and incorporated [7]. Children at schools throughout the country will receive healthier meals and more instruction on healthy living and exercise [8]. Education Reform System of Thailand provided partly through merging and optimizing its more than 20,000 schools were nationwide [9]. It's meanwhile rote learning is common but a surfeit of physical-education instructors. Many head teachers lack the authority to hire or fire their own staff [10].

The UNICEF reported that $85 \%$ of children aged 3-5 years attending pre-primary education or early childhood education programs [11]. In 2016, 86\% of children from the poorest households were attending early childhood education programs. Thailand's commitments, adequate allocation of resources, as well as a special focus on children from poor families have clearly yielded results as seen in the data [12]. All children ages 0-5 years are progressively cared for through quality ECD services and in protective and nurturing family environments. $34 \%$ fathers engage in four or more activities that promote learning. $15 \%$ of children aged 3-5 years are not attending an early childhood education programs. $59 \%$ of children younger than 5 years do not have at least three books at home [13]. Although participation in early childhood education makes a huge difference in a child's development, around 15\% of children aged 3-5 years are not attending an early childhood education program [14]. Early Childhood Education curriculum set 12 desirable characteristics standards including physical development consists of 2 standards: Emotional development consists of 3 standards: Social development consists of 3 standards: and the development of intelligence consists of 4 standards [15].

The Child Development Centers (CDCs) in Thailand is supervised by 5 main Ministries, including the Ministry of Social Development and Human Security, Ministry of the Interior Ministry of Education, The Ministry of Public Health, and the Ministry of Labor, which is 5 co-ordinations, contribute to the development of quality child development centers [16] are in charge of many sectors in the area of custody of the local government organization, number 758,435 centers throughout of Thailand. Child care teachers' or caregivers' position and the head of the CGCs, these are hired by budget, government subsidies and local income must have general qualifications and not be prohibited. To have qualifications at least a bachelor's degree in education all majors, or another the position that the CDC defines a position-specific qualification, have a teaching professional license, and must have passed the performance evaluation according to the score criteria and Ministry of Interior set with a score of not less than 75 percent [17].
Identity Structure Analysis (ISA), is a structural representation of the individual's existential experience, in which the relationships between self and other agents are organized in relatively stable structures over time with the emphasis on the socio-cultural milieu in which self relates to other agents and institutions" [18]. However, the emphasis on education in today's society makes it much harder for people with low levels of education to develop a positive social identity [19]. How is the concept of identity relevant to educational research? There is a large part of the educational sector with a connection to religious institutions [20]. What about the identity of the Child Development Centers (CDCs) throughout Thailand? The schools with many levels, there are many classrooms per grade, many teachers, and various learning opportunities. Are students from rural schools still studying at a lower level than students from city schools? What sets a rural school apart from the city school? [21]. Overall on students from rural schools are disadvantaged with teacher learning resources and extracurricular activities.

As above are the important questions; why do the rural students leave out from their rural schools to the city schools all the students' grade levels that adding early childhoods from rural communities to the schooling cities? The government has various welfare both specialized teachers, standard school buildings, schools were within the village, and these students struggled for themselves or as their parents' values. The number of students in the countryside started to decline. Some schools don't have students in their classes. This situation in Thailand is not referred to as educational asylum. The state has invested a budget for the Office of the Local Administration to set up eight thousand child development centers nationwide. The child center prevents young children from traveling far from the village to the city for their learning. How will the child development center create an identity? Does each community identity accept? This is the main cause of this research study.

Educational expectation, educational expectations will further find a difference between students from rural schools and students from city schools. Only 30\% of students from rural schools expect that will complete at least a university degree while about $50 \%$ of the students from city schools would expect that. The distant geography whereas rural students who stay in villages, there is a shortage of vocational and skilled work models that will set an example for students living in the countryside. Eventually, though, these students are ready to continue their studies. But students in the countryside will have to travel to and from longer distances, or they may have to move to a bigger city to continue their studies. Where the field of study may not be able to find work in the home country, these are variables that make a small number of rural students want to continue their education.

\section{Methodology}

Designing for this research study is the process of 
collecting and analyzing numerical data. It can use to find patterns and averages, make predictions, test causal relationships, and generalize results to wider populations to attempt for establishing the cause-effect relationships among the variables.

\section{Research purposes}

To assess the children's parents of their perceptions to their identities of their local CDCs.

To assess the teachers and caregivers of their perceptions to their identities of their CDCs.

To associate between the perceptions of children's parents and their attitudes' to their global and local identities at the local CDCs.

To associate between the perceptions of teachers or caregivers and their attitudes' to their local identities at their local CDCs.

\section{Research procedures}

Quantitative research is used, including communication researchers, affecting individuals with people's perceptions on the local identity-related attitude in the CDCs for protecting educational asylum of early childhoods from rural communities to the schooling cities in Thailand.

In terms of the CDCs including the 10 contexts to order of the Department of Local Administration No. 246/2014, this step has modified the CDCs to the questionnaires for children's parents, teachers and caregivers' perceptions on the questionnaires in the CDCs to create.

Because this project was supported by the Office of Health Promotion Foundation (HPF) are the government agencies that status is not a government agency or state enterprise established under the Health Promotion Fund Act under the supervision of the Prime Minister; World Health Assembly Resolution (WHAR), and Health Promotion and Health LifeStyle (HPHLs) under the World Health Organization (WHO).
We have to express our appreciations to the children's parents, teachers, and caregivers, in the 15 Child Development Centers for sharing their pearls of wisdom with us during the administration of their perceptions to their responses in this research project throughout Thailand.

The research instruments were invented on the three options that including; the questionnaire on global local identities of the 15-representative Child Development Centers to assess the children's parents of their perception to the identified toward the Child Development Centers' identities for protecting educational asylum of their early childhoods from rural communities to the schooling cities.

\section{Sample size}

There is 19,171-Child Development Centers under the Department of Local Administration in the six CDCs Regions. A Simplified Formula for Proportions Yamane (1967:886) [23] provides to estimate the proportion of the population. This research study was used to calculate the sample size in six regions such as Northern, North-eastern, Central, Eastern, Western, and Southern Regions throughout Thailand. Each region was selected of the five CDCs whereas consist of 30 CDCs:

1. Children' parents consist of 300 (each the CDC's responses as 10 children's parents)

2. Teachers and Caregivers consist of 300 personnel (each CDC's responses as 10 Teachers and Caregivers) (Figure 1)

\section{Research Instruments}

The my CDC Identity Inventory (MCDCII): Modified the 25-item My CDC Identity Inventory (MCDCII) Designing a three-point response format (Seldom, Sometimes and Most of the Time) with was designed the version of the MCDCII by Santiboon [44] in 5 scales; each scale obtains five items, namely; Identity Satisfaction (ISA), Identity Competitiveness (ICM), Strong-Sense Identity (SSI), Complex Physical Indoor

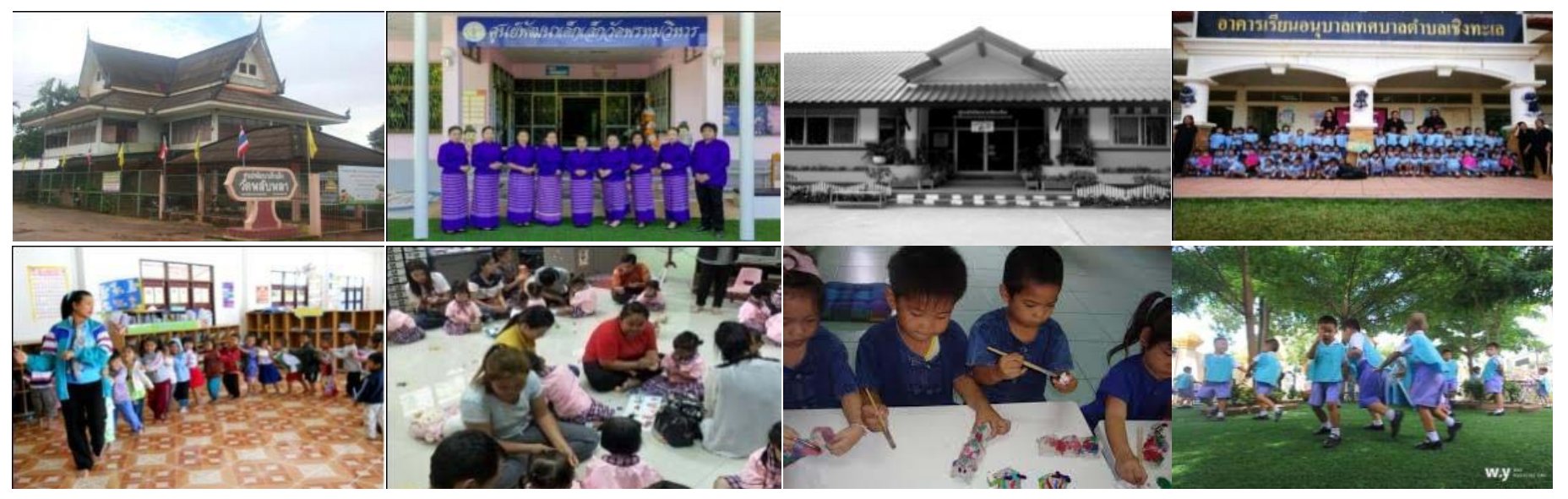

Figure 1: Some samples of the CDCs with the locations and early childhoods' activities with their parents, teachers, and caregivers in indoor and outdoor environments. Source: The Department of Local Administration, [27]. 
and Outdoor Identity (CPIOI), and Identity Cohesiveness (ICO) scales, respectively. We argue that traditional methods focus on providing leadership tools, but impactful training must also focus on the goals of leadership and the creation of an "educational identity" to assess the parents' perceptions after the authors' reading the questions or they are able to mark by themselves, possibly.

The Questionnaire on Teacher Identity Interaction (QTII): The 30-item Questionnaire on Teacher Identity Interaction (QTII) in five scales, each scale obtains six items. The teachers and caregivers were responses to five options (Never (0), Seldom (1), Neither Seldom nor Often (2), Often (3), and Always (4)). The five scales of the QTII included Teacher Leadership Identity (TLI), Teacher Helpfulness/ Friendly Identity (THFI), Children Responsibility/Freedom Identity (CRFI), Children Understanding/Satisfaction Identity (TURI), and Outdoor and Indoor Environmental Identity (OIEI) [24].

The Local Identity-Related Attitude (LIRA): Modified the short version of the 10-item Local Identity-Related Attitude (LIRA) that each measured on a 5-point Likert scale. A Likert scale is the sum of responses on several Likert items [25] on Strongly Disagree (1), Disagree (2), Neutral (3), Agree (4), and Strongly agree (5); these items comprise with 10 items [26]).

\section{Data analysis}

The internal consistency reliabilities (alpha coefficients) were computed for each of the derived factors for the QTII (scoring meanwhile 0-4), and the LIRA (scoring meanwhile 1-5) forms, and the MCDCII (scoring meanwhile 1-3) forms. Factorial validity and adequacy of fit for the dimensionality of the MCDCII, QTII, and the LIRA through the principal component analyses. Using the correlations $(r, R$, and $\beta)$ and the determination of efficient predictive value $\left(R^{2}\right)$ analyzed with the compare means of two variables.

\section{Results/findings}

\section{Validation of the MCDCII}

Tables 1 show an average item means for each of five MCDCII scales on 25 items. For the remaining five scales, ISA, ICM, SSI, CPIOI, and the ICO scales with Internal Consistency (Cronbach alpha) Reliability was analyzed. Something got a separate summary of these values for the MCDCII in Table 1.

Table 1 reported the $\alpha$-reliability for the MCDCII, it ranged from 0.646 to 0.779 . The scale means ranged from 2.269 (SSI scale) to 2.437 (ICO scale) on the MCDCII Form. The item means ranged from 11.347 to 12.187 . Standard deviations ranged from 1.872 to 2.414 . The variance ranged from 3.506 to 5.836. The F-test analysis is significant as .001 all on five scales. The MCDCII is a reliable instrument for using to assess the CDCs in different CDC areas.

\section{Validity of the QTII}

Using the 30-item Questionnaire on Teacher Identity Interaction (QTII) on five scales; TLI, THFI, CRFI, TURI, and OIEI assessed parents, teachers, and caregivers in the 30CDCs with $\alpha$-Reliability analysis. A summary of these values received separately for QTII reported in Table 2.

Table 2 reported the $\alpha$-reliability for the different QTII ranged from 0.641 to 0.667 . The scales ranged from 2.612 (OIEI scale) to 2.827 (TLI scale) on the QTII Form. The items mean they ranged from 15.673 to 18.960 . Standard deviations ranged from 1.816 to 3.000 . The variance ranged from 7.932 to 9.017 . The F-test analysis is significant at .001 all on five scales. The QTII is a reliable instrument for the CDCs analysis in different areas.

\section{Validity of the Local Identity-Related Attitude (LIRA)}

Using the 10-item Local Identity-Related Attitude (LIRA) in two versions for assessing parents, teachers', and caregivers' perceptions of their CDCs and their attitudes toward identities were assessed. The attitude scale previously validated that we discussed it for Children parents' version (CPV) and Teachers and Caregivers' Version (TCV) Forms. The minimum score is 10 and the maximum score is 50 , it reports the results in Table 3.

Table 3, the $\alpha$-reliability coefficients of the LIRA in the CPV and the TCV Forms are 0.781, and 0.754; the item means as 36.327 , and 37.850 , the grand mean score as 3.633 , and 3.785 in devoted of the SD as 4.482, and 5.039, the variance value is 20.087, and 25.392, and significant of F-test at the level of .001

Table 1: Item Mean, Scale Average Mean, S.D., Variance, $\alpha$ - Reliability, and F-test for the MCDCII.

\begin{tabular}{|c|c|c|c|c|c|c|}
\hline Scale & Item Mean & $\begin{array}{c}\text { Grand } \\
\text { Mean }\end{array}$ & S.D. & Variance & $\alpha$-Relia. & F-test \\
\hline ISA & 11.390 & 2.278 & 2.414 & 5.836 & 0.779 & $9.353^{* * *}$ \\
\hline ICM & 11.806 & 2.361 & 1.981 & 3.922 & 0.587 & $5.835^{* * *}$ \\
\hline SSI & 11.347 & 2.269 & 2.323 & 5.398 & 0.733 & $24.105^{\star * *}$ \\
\hline CPIOI & 11.450 & 2.290 & 1.872 & 3.506 & 0.646 & $10.078^{* * *}$ \\
\hline ICO & 12.187 & 2.437 & 2.169 & 4.708 & 0.656 & $5.138^{* * *}$ \\
\hline $\mathrm{N}=300,{ }^{*} \rho<.05,{ }^{* *} \rho<.01,{ }^{* * *} \rho<.001$ & & & \\
\hline
\end{tabular}

Table 2: Item Mean, Scale Average Mean, Standard Deviation, Variance, a-Reliability, and F-test for the QTII.

\begin{tabular}{|c|c|c|c|c|c|c|}
\hline Scale & $\begin{array}{c}\text { Item } \\
\text { Mean }\end{array}$ & $\begin{array}{c}\text { Grand } \\
\text { Mean }\end{array}$ & $\begin{array}{c}\text { Standard } \\
\text { Deviation }\end{array}$ & Variance & a-Reliability & F-test \\
\hline TLI & 18.960 & 2.827 & 2.816 & 7.932 & 0.651 & $115.931^{* * *}$ \\
\hline THFI & 16.653 & 2.777 & 2.857 & 8.167 & 0.667 & $102.836^{* * *}$ \\
\hline CRFI & 16.820 & 2.803 & 2.931 & 8.590 & 0.641 & $88.873^{* * *}$ \\
\hline TURI & 16.600 & 2.767 & 3.000 & 9.017 & 0.627 & $140.370^{* * *}$ \\
\hline OIEI & 15.673 & 2.612 & 2.989 & 8.936 & 0.665 & $177.742^{* * *}$ \\
\hline $\mathrm{N}=300,{ }^{*} \rho<.05,{ }^{* *} \rho<.01,{ }^{* * *} \rho<.001$ & & & \\
\hline
\end{tabular}

Table 3: Item Mean, Scale Average Mean, Standard Deviation, Variance, $\alpha$ - Reliability, and F-test for the LIRA.

\begin{tabular}{|l|c|c|c|c|c|c|}
\hline \multicolumn{1}{|c|}{ Scale } & $\begin{array}{c}\text { Item } \\
\text { Mean }\end{array}$ & $\begin{array}{c}\text { Grand } \\
\text { Mean }\end{array}$ & $\begin{array}{c}\text { Standard } \\
\text { Deviation }\end{array}$ & Variance & $\alpha$-Reliability & F-test \\
\hline CPV Form & 36.327 & 3.633 & 4.482 & 20.087 & 0.781 & $10.289^{* * *}$ \\
\hline TCV Form & 37.850 & 3.785 & 5.039 & 25.392 & 0.754 & $7.809^{* * *}$ \\
\hline $\mathrm{N}=300,{ }^{*} \rho<.05,{ }^{* *} \rho<.01,{ }^{* * *} \rho<.001$ & &
\end{tabular}


too, respectively that using the individual children' parents, and teachers and caregivers as the unit of analysis.

It is also considered important to investigate associations between parents' perceptions of the CDC identity inventory and their local identity-related attitudes to protect educational asylum in early childhoods from rural communities to schooling cities in local identities differentiated from the Local Child Development Center toward identities. This suggests that the scales are valid and reliable for measuring children parents' attitudes to CDC identities, the results as reported in Table 4.

To investigate associations between teachers, and caregivers' perceptions on teacher identity interaction of the CDC identity and the local identity-related attitude for protecting educational asylum of early childhoods from rural communities to the schooling cities in the global and local identities are differentiated with the Local Child Development Centers toward identities. The selection of an evaluation and assessment instruments suitable for answering the fifth research objective is confirmed, the results as reported in Table 5.

As reported in Tables 1-3 showed off the associations between children's parents' perceptions of the CDC identity inventory, and between teachers and caregivers' perceptions

Table 4: Associations between MCDCII Scales and the LIRA on the CPV Version to the CDCs in Terms of Simple and Multiple Correlations, Standardized Regression Coefficient, and Determination Coefficient Predictive Value.

\begin{tabular}{|c|c|c|c|}
\hline Scale & Grand Mean & Simple Correlation (r) & $\begin{array}{c}\text { Standardized Regression } \\
\text { weight Attitude }(\beta)\end{array}$ \\
\hline ISA & 2.278 & $0.226^{\star * \star}$ & $0.188^{* *}$ \\
\hline ICM & 2.361 & $0.178^{* *}$ & $0.137^{*}$ \\
\hline SSI & 2.269 & $0.158^{* *}$ & $0.167^{*}$ \\
\hline CPIOI & 2.290 & $0.127^{*}$ & $0.192^{* *}$ \\
\hline $\mathrm{ICO}$ & 2.437 & $0.259^{* \star *}$ & $0.164^{*}$ \\
\hline CPV Form & 3.633 & & \\
\hline $\begin{array}{c}\text { Multiple } \\
\text { Correlation (R) }\end{array}$ & \multicolumn{3}{|c|}{$0.699^{\star \star}$} \\
\hline $\begin{array}{c}\text { Determination } \\
\text { Coefficient } \\
\text { Predictive } \\
\text { Value }\left(\mathrm{R}^{2}\right)\end{array}$ & \multicolumn{3}{|c|}{$0.488^{* *}$} \\
\hline$N=300,{ }^{*} \rho<.05$ & $5,{ }^{* *} \rho<.01,{ }^{* * *}$ & ${ }^{*} \rho<.001$ & \\
\hline
\end{tabular}

Table 5: Associations between QTII Scales and the LIRA on the CPV Version to the CDCs in Terms of Simple and Multiple Correlations, Standardized Regression Coefficient, and Determination Coefficient Predictive Value

\begin{tabular}{|c|c|c|c|}
\hline Scale & Grand Mean & $\begin{array}{c}\text { Simple } \\
\text { Correlation (r) }\end{array}$ & $\begin{array}{c}\text { Standardized } \\
\text { Regression weight } \\
\text { Attitude }(\beta)\end{array}$ \\
\hline TLI & 2.827 & $0.232^{* * *}$ & $0.265^{* * *}$ \\
\hline THFI & 2.777 & $0.215^{\star * *}$ & $0.221^{* *}$ \\
\hline CRFI & 2.803 & $0.208^{* *}$ & $0.225^{* *}$ \\
\hline TURI & 2.767 & $0.151^{\star *}$ & $0.241^{\star \star}$ \\
\hline OIEI & 2.612 & $0.249^{* * *}$ & $0.421^{* \star *}$ \\
\hline CTV Form & \multicolumn{3}{|c|}{3.785} \\
\hline Multiple Correlation (R) & \multicolumn{3}{|c|}{$0.782^{\star \star \star}$} \\
\hline $\begin{array}{l}\text { Determination Coefficient } \\
\text { Predictive Value }\left(R^{2}\right)\end{array}$ & \multicolumn{3}{|c|}{$0.611^{* * *}$} \\
\hline
\end{tabular}

on teacher identity interaction MCDCII scales, and the QTII scales to their Local Identity-Related Attitude (LIRA) were assessed. Statistically significant was analyzed with $\overline{\mathbf{X}}$, S.D, $\sigma^{2}$, F-test, simple and multiple correlations, regression efficient $(\beta)$, and determination of efficient predictive value $\left(R^{2}\right)$ to predict. The determination of efficient predictive $\left(R^{2}\right)$ value indicates that $49 \%$ and $61 \%$ of the variance in parents, teachers, and caregivers' responses of the local identityrelated attitudes were attributable in their $M y C D C$ Identity Inventory (MCDCII) scales, and the Questionnaire on Teacher Identity Interaction (QTII) are significant, correlatively.

\section{Discussion/analysis}

Why does the determination efficient predictive value $\left(\mathrm{R}^{2}\right)$ indicates that $30 \%$ of the 300 -children's parents who are accepted of the identities of the 30-CDCs on the cohesiveness, competitiveness, physical indoor and outdoor environmental development, satisfaction, and strong-sense identities, respectively? From the perspective of the parents to their own local child development center, because of mistrust, or lack of faith to send children to develop their mind, physically, and intelligence, or because most of the environment at the Child Development Center is located in the temple locations, or mostly village boarding schools, old buildings, inexhaustible environments, or a way of development can't be carried out or managed. Therefore, parents do not send their children into the child development centres.

Over the past two and a half decades, all children in Thailand receive 12 years of free basic education, plus 3 years of pre-primary schooling. Secondary school net enrollment rose impressively from $31 \%$ in 1990 to $78 \%$ in 2011 . $82 \%$ of girls are enrolled in secondary education, $8 \%$ higher than boys [48]. Small schools, especially, face their own set of challenges. These schools are much more expensive to operate and do not generally deliver high quality education. The number of primary school students fell from 7.45 million in 1982 to 5 million in 2012 due to falling birth rates. The number of small schools with less than 20 students per grade increased dramatically from 15,000 in 1993 to 19,800 in 2010. Small schools are hindered by a severe lack of teachers, teaching materials and physical infrastructure. How to improve the quality of small schools and ensure quality education for all?

What are the teachers and caregivers' outcomes of their CDCs indicate of $74 \%$ of the early childhood in their CDCs can protect educational asylum of early childhoods from rural communities to the schooling cities with their identities of the CDCs? Why are they able to manage and develop their CDCs, possibly? [29]. The operation conditions of Child Development Centers according to the standards of the Department of Local Administration with the most administration were buildings, environment, and safety, followed by academic and curriculum activities. Personnel and management, and community participation, and support are main affected, respectively [30]. 
$44 \%$ of children's parents predict that identity satisfaction and the physical indoor and outdoor identity scales aren't good identities that except on the cohesiveness and competitiveness identities. There was a more favorable attitude towards their CDCs identity inventory. The results are not sure for protecting educational asylum early childhoods from rural communities to the schooling cities if the children's parents have the social values for taking their children are selected. The local Child Development Centers must be made sense to their CDCs' identities to develop the identity of the child development centers meanwhile they must be recognized by the local parents [31]. According to the government spending a lot of funding to enable the early childhoods to develop physically, mentally, and intellectually and prepare for entering a compulsory basic learning system [32]. Because children's outcomes are influenced by the multiple environments they encounter, including both family and child care settings, there has been a growing interest in research about the effects of child care experiences on children's development [33].

Parents should be made sense increasingly common, early childhood care plays an important role in children's development and provides valuable support to families with young children. It is therefore important to understand the impact of these services and to ensure their quality and accessibility [34]. Therefore, a substantial majority of young children now regularly experience child care prior to their entry into school: rates of care for preschool-aged children are now higher than for infants and toddlers. Recent estimates indicate that nearly two-thirds of all 3- to 5-yearold children attend some form of the regular child care prior to kindergarten. Given these high child care usage rates, both parents and professionals have sought to understand the impact of these experiences on children's cognitive and social development [35].

The effects of the parents and local organization administrators reflected that small schools could provide educational opportunity for children to learn near home and small schools develop good habit and well personality of the children, limiting in budget and small number of teachers. School and classroom observation, individual interviews, and dialog, it demonstrated patterns of academic, human resource and budget management within the small schools, and factors affecting the efficiency and limitation in improving quality of small schools by recognition of views and needs of students and their families, potentials of small schools, support from the local organization administrators and educational ministry's policy [36].

Therefore, improving the quality of teachers and addressing the severe teacher shortages - especially for the vast number of small rural schools - should be at the center of Thailand's reform initiatives if the country is serious about tackling the widespread low education quality and high disparity in educational performance between socioeconomic groups. As many as 110,725 out of 353,198 classrooms in Thai primary and secondary schools are critically short of teachers. Given the severity of the problem, a massive outlay would be required to staff all classrooms in the country adequately. In fact, under the current situation where there are more than 31,000 schools nationwide, Thailand would need to recruit, train, and deploy 108,000 new teachers - an increase of nearly $27 \%$ of the teaching force [37].

The small schools were complex problems and were considered an important problem in solving the educational inequality in the country. The Equitable Education Fund (EEF) tried to analyze an in-depth research to solve the problems of small schools and find the clear systematic reform in order to support the systematic research process which will lead to policy proposals that will help the work of government's education reform efficiently and sustainably. This proposed plan will be in agreement with the Equitable Education Fund (EEF), which has a limited budget of only $0.5 \%$ in the education system. We therefore set out the problem of small protected schools in remote areas of the community that cannot be dissolved and merged [38].

Thailand currently had small schools with less than 120 students per a school and the distance from the nearest neighboring school was no less than 10 kilometers, which the total schools were 1,594 schools. Most of which were located in remote areas on mountains or islands, this group of schools currently provided education to 100,000 students. If we dissolved and merged this group of schools, it would cause the students who would travel to nearby schools for a longer distance around 10-20 kilometers. Therefore, the Equitable Education Fund (EEF) will use the systematic research process to determine the work problems that will lead to policy proposals for the educational equality reform. For these Protected Schools, they will be able to provide quality education for children and youth in the area sustainably, consisting of 3 sub-problems: 1 . Solving problems with data and evidence, 2 . Resource allocation using equality principles, and 3. Innovative teaching and learning management [39].

\section{Conclusion}

Early childhood education curriculum aims to develop all children to have quality and continuous development of physical, emotional, mental, social, and intellectual development. Identity Structure Analysis (ISA), is a structural representation of the individual's existential experience, in which the relationships between self and other agents are organized in relatively stable structures over time with the emphasis on the socio-cultural milieu in which self relates to other agents and institutions. All too often religious faith becomes mono-logical in a way that impedes rather than promotes personal development. What about the identity of the Child Development Centers (CDCs) throughout Thailand? There are any questions about whether these differences 
lead to changes in academic achievement. Are students from rural schools still studying at a lower level than students from city schools? In general, what sets a rural school apart from the city school? Overall on students from rural schools are disadvantaged with teacher learning resources and extracurricular activities. This situation in Thailand is not referred to as educational asylum. The state has invested a budget for the Office of the Local Administration to set up eight thousand child development centers nationwide.

In this research study, focused on the 19,171-Child Development Centers under the Department of Local Administration, Ministry of Interior whereas the six educational regions; Northern, Northeastern, Central, Western, Eastern, and Southern Regions. Designing the quantitative research method to assess the children's parents', and teachers' and care givers' perceptions of their 30-Local Child Development Centers whereas in the six regions, each region was selected of the five CDCS. The Local Child Development Centers' perceptions were obtained using the 25-item My CDC Identity Inventory (MCDCII) modified from the original My Class Inventory in five scales on three options were assessed the children's parents' perceptions. Teacher and CaregiverEarly Childhood interactions were assessed with the 30-item Questionnaires on Teacher Identity Interaction (QTII) in five scales on five options were assessed teachers" and caregivers' perceptions.

Both these questionnaires are valid and reliable with Factor Loading analysis, intercorrelation circumplex nature by Pearson's Correlation and internal consistency Cronbach alpha coefficient reliability is confirmed. The 10-item Teat of Identity-related attitudes were assessed with a short Attitude scale. The questionnaires were translated into the Thai language and administered to a sample of 300 children's parents and 300 teachers and caregivers at the 30 Local CDCs. Statistically significant was found that of the determination efficient predictive value $\left(\mathrm{R}^{2}\right)$ indicates that $30 \%$ of the 300 -children's parents who are accepted of the identities of the 30-CDCs on the cohesiveness, competitiveness, physical indoor and outdoor environmental development, satisfaction, and strong-sense identities, respectively. Teachers and caregivers' outcomes of their CDCs indicate of 74\% of the early childhood in their CDCs are able to protect the educational asylum of early childhoods from rural communities to the schooling cities with their identities of the CDCs, significantly.

Associations between children's parents' perceptions of the CDC identity inventory (MCDCII scales) and their local identity-related attitude (CPV Form) in terms of Simple ( $r$ ) and Multiple Correlations (R), Standardized Regression Coefficient $(\beta)$, and Determination Coefficient Predictive Value $\left(\mathrm{R}^{2}\right)$ were assessed. These associations are positive for the scales of Identity Cohesiveness ( $\overline{\mathrm{X}}=2.437$ ), Identity Competitiveness ( $\bar{X}=2.61$ ), Physical Indoor and Outdoor Identity ( $\bar{x}=2.290$ ), Identity Satisfaction ( $\overline{\mathrm{X}}=2.278$ ), and Strong-Sense Identity
$(\overline{\mathrm{X}}=2.269)$, respectively. The multiple correlation $\mathrm{R}(\mathrm{R}=$ $0.699, p<.01$ ) is significant. The $\mathrm{R} 2$ value indicates that $49 \%$ of the variance in children parents' perceptions' identityrelated attitude outcomes to their local CDCs environment inventory was attributable to their perceptions of their CDCs identity inventory environments.

In terms of associations between teachers' and caregivers' perceptions of teacher identity interaction of the CDC identity and the local identity-related attitude, the simple correlation values (r), which show significant positive directive correlations $(p<0.05)$. These associations are positive for the scales of Teacher Leadership Identity ( $\bar{X}=2.847)$, Children Responsibility/Freedom Identity $(\bar{X}=2.803)$, Teacher Helpfulness and Friendly Identity $(\bar{X}=2.777)$, Children Understanding/Satisfaction Identity ( $\overline{\mathrm{X}}=2.767)$, and Physical Outdoor and Indoor Environmental Identity ( $\bar{X}=2.612$ ), respectively. The second type of analysis consisted of the more conservative standardized regression coefficient $(\beta)$ which measures the association between teachers' and caregivers' perceptions' of their Children Development Centers to the identity-related attitudes' creative towards The CDCs' identities when the effects of relationships between the scales are controlled. The multiple correlations $\mathrm{R}(\mathrm{R}=0.782$. $p<.001$ ) is significant, and The $\mathrm{R}^{2}$ value indicates that $61 \%$ of the variance in teachers and care givers' perceptions' of their identity-related attitude outcomes to their local CDCs environment inventory was attributable toward their CDCs' teachers and caregivers identity environments are responded.

Finally, The Child Development Centers in Thailand, for more than 15 years, the Thai Child Development Foundation (TCDF) has a sustainable influence on the lives of children in need. The TCDF projects are providing customized care for each child in close cooperation with their parents or other daily life caregivers, teachers, and local healthcare providers [40]. There are 754,424 centers of the Child Development Centers are under the supervision of the Local Government Organization (LGO), Ministry of Interior. General standards relating to personnel management, staff, teachers, and educational personnel of the local administration organization, the municipality's educational personnel management criteria and methods apply mutatis mutandis to the personnel administration of the teachers and educational personnel of the Sub-District Administrative Organization. Office of Welfare Promotion and Protection of Children, Youth, the Disadvantaged and the Elderly (CAT), Ministry of Social Development and Human Security to adopt a five-year operational framework under the draft National Child and Youth Development Plan [41].

\section{Acknowledgement}

Firstly we would like to thank the children parents, teachers, and caregivers for giving us the wonderful opportunity to complete our empirical data under their perceptions and 
responses of our research instruments and sent them back to us via mail, Facebook, and others, these are truly an honor.

Thank you for all the advice, ideas, moral support, and patience in guiding us through this research project. Thank you for your enthusiasm for the study of the quantitative method.

We would also like to show our gratitude to the Assoc. Prof. Dr. Gregory Alexander of Department of Post Graduate Studies, Faculty of Humanities, Central University of Technology, Free State (CUT), Bloemfontein, South Africa whereas signature the MOU between our universities for sharing their pearls of wisdom with us during the course of this research, for their comments on an earlier version of the manuscript, although any errors are our own and should not tarnish the reputations of these esteemed persons.

\section{References}

1. Ministry of Education Thailand (MOE). Education system of Thailand Does Thailand have a good education system? 2018. http://www. en.moe.go.th/enMoe2017/index.php/ministry-profile/executivesprofile/

2. UNICEF. Thailand education overview. 2018. https://www. bangkokpost.com/thailand/general/1660508/un-praises-thailand-forstrides-in-early-schooling

3. Michael R, Trines S. Education in Thailand: World Education News + Reviews (WENR). World Education Services (WES). 2018. https:// wenr.wes.org/2018/02/education-in-thailand-2

4. Engchun R, Sungtong E, Haruthaithanasan T. Homeschooling in Southern Thailand: Status and proposed guidelines for learning process management. Kasetsart J Soc Sci. 2018; 39: 502-508.

5. Mala D. Government seeks to close the great class divide. Bangkok Post. 2018. https://www.bangkokpost.com/thailand/special-reports/1391622/ govt-seeks-to-close-the-great-class-divide

6. Wipatayotin A. Ex-education chief urges reform. Bangkok Post 2018.https://www.bangkokpost.com/thailand/general/1391518/exeducation-chief-urges-reform

7. Dachakupt $P$. The current innovation in curriculum development in Thailand. International Journal of Curriculum and Practice. 1999 https://www.jstage.jst.go.jp/article/jcrdaen/1/1/1_KJ00006742072/_pdf

8. The Nation News. Thailand to boost average height with better school meals. The Nation. 2015. http://www.nationmultimedia $\mathrm{com} /$ breakingnews/Thailand-to-boost-average-height-with-betterschoo-30264650.html

9. Office of the Basic Education Commission. Early Childhood Curriculum 2017. Ministry of Education. 2017. https://www.obec.go.th/wp-content/ uploads/2019/11/english_version.pdf

10. The Economist. Poor schools are at the heart of Thailand's political malaise. 2017. https://www.economist.com/asia/2017/01/19/poorschools-are-at-the-heart-of-thailands-political-malaise

11. UNICEF. UN praises Thailand for strides in early schooling. Bangkok Post. 2019. https://www.bangkokpost.com/thailand/general/1660508/ un-praises-thailand-for-strides-in-early-schooling

12. Post Reporters. Young minds get a chance to grow: Young begin to be heard. Bangkok Post. 2020: https://www.bangkokpost.com/thailand/ politics/1972795/young-begin-to-be-heard

13. UNICEF Thailand: for Every Child. Early childhood development 2014. https://www.unicef.org/thailand/what-we-do/early-childhooddevelopment
14. Sangnapabowon W, Changdapa C. Early childhood care and education. Ministry of Education. 2012: http://backoffice.onec.go.th/ uploaded/Category/EngBook/EFA-Goal1EarlyChildhoodCareAndE du-05-03-2012.pdf

15. Ministry of Education. Early Childhood Curriculum B.E. 2560. 2017 https://www.obec.go.th/wp-content/uploads/2019/11/

16. Ministry of Labor. Child labor and forced labor reports. : 2018. https:// www.dol.gov/agencies/ilab/resources/reports/child-labor/thailand

17. Ministry of Interior. The general standard quality of child care teachers' or caregivers' position and the head of the Child Development Center. http://www.dla.go.th/upload/ebook/column/2017/4/2199_5930.pdf

18. Weinreich $P$, Saunderson W. Analyzing identity: Cross cultural, societal and clinical contexts. Ulster University. Routledge. 2013. https://pure. ulster.ac.uk/en/publications/analysing-identity-cross-cultural-societaland-clinical-contexts-3

19. Economic and Social Research Council. The wellbeing effect of education. 2014: https://esrc.ukri.org/news-events-and-publications/ evidence-briefings/the-wellbeing-effect-of-education/

20. Lövgren J. How is the concept of identity relevant to educational research? https://www.researchgate.net/post/How_is_the_concept of_identity_relevant_to_educational_research

21. PISA Thailand. Is there a difference between a rural school and an city school? The institute for the Promotion of Teaching Science and Technology. 2019. https://pisathailand.ipst.ac.th/issue-2019-41/

22. Tasty Thailand. The education system in Thailand: A terrible failure. 2019. https://tastythailand.com/the-education-system-in-thailand-aterrible-failure/

23. Yamane T. Statistics, an introductory analysis, 2nd Ed, New York: Harper and Row. 1967.

24. Santiboon T. Appropriating characteristics of the 21st century teachers to transform of the Thailand 4.0 policies. Afr J Pedagogy Curriculum. 2017; 4: 48-64.

25. Likert R. A technique for the measurement of attitudes. Arch Psychol. 1932; 22: 55.

26. Department of Local Administration, Ministry of Interior. The Child Development Centers in Thailand. 2020. http://resource.thaihealth. or.th/taxonomy/term/4805

27. The Word Bank. Wanted: A quality education for all in Thailand. 2020 https://www.worldbank.org/en/country/thailand/publication/wanted---aquality-education-for-all-in-thailand

28. Songmueang T, Wichai Napapong W, Ladlia K, Kaosaiyaporn O. The operation conditions and problems of the early childhood development center under local administrative organization in Southern Andaman provincial cluster. Silpakorn Univers J. 2020.

29. Teppun P, Chanjarain J, Siririth W. State and Problem of Child Development Centers of Local Administrative Organization in Wiangchiangrug District Chiangrai Province. Veridian E-Journal, Slipakorn University. 2015; 8: 2015.

30. Sordsaen S, Songwiwat S, Suwannarak P. Problems of early childhood development center of local administrative organization, Buriram. Graduate Research Conference. 2013. https://gsbooks.gs.kku. ac.th/56/grc14/files/hmp19.pdf

31. Jetanavanich S. Small problems for teachers of the Child Development Centers. 2012: https://www.gotoknow.org/posts/9300

32. Goonchamorin K, Phudee T. A study of problems and guidelines on development of the Child Development Center at Kalasin Province. Nakhon Phanom Univers J. 2014; 4.

33. McCartney K. Child care - Early childhood education and care. Harvard University, USA. 2017. http://www.child-encyclopedia.com/child-careearly-childhood-education-and-care/ 
34. Peisner-Feinberg ES. Child care and its impact on young children's development. FPG Child Development Institute, University of North Carolina at Chapel Hill, USA. 2017.

35. East Asia and Pacific. Problems on Education in Thailand. 2020 https://blogs.worldbank.org/search?f[0]=regions:275\&f[1]=language:en

36. Wannagatesiri $\mathrm{T}$, Nukultham $\mathrm{K}$, Kruea-In $\mathrm{N}$, Thongperm A. Lesson learned from the experiences of small schools in Thailand. ScienceDirect. Procedia - Soc Behavioral Sci. 2014; 14: 1095-1100.

37. East Asia and Pacific. Problems on Education in Thailand. 2020 https://blogs.worldbank.org/search?f[0]=regions:275\&f[1]=language:en

38. Equitable Education Research Institute (EEFI). Small Protected
Schools, a big challenge of Thai education. 2019. https://research.eef. or.th/small-protected-schools-a-big-challenge-of-thai-education/

39. Pattrawat K. Small protected schools, a big challenge of Thai education. Deputy Manager of the Equitable Education Fund (EEF). 2019. https:// research.eef.or.th/small-protected-schools-a-big-challenge-of-thaieducation/

40. Thai Child Development Foundation. Sustainable support for children in need. 2017. https://thaichilddevelopment.org/

41. Office of Welfare Promotion and Protection of Children, Youth, the Disadvantaged and the Elderly (CAT), Ministry of Social Development and Human Security. Child information. 2017. http://dcy.go.th/introduction_management.php 